\title{
Sex Education and Religion
}

Ediled by Michael J. Reiss \& Shaikh Abdul Mabud. Cambridge: The Islamic Academy. 1998, 277pp.

The far-reaching implications of the debate surrounding sex education in state schools are summed up by the late Professor Syed Ali Ashraf in his Foreword to this book: "We are up against a tremendous conspiracy to dethrone the religious concept of a human being from the minds of people." Sex education is "just a modus operandi" of the "secularist philosophy" underpinning this conspiracy (p. 3).

In presenting a number of essays on sex education from different faith and nonfaith perspectives, the editors have succeeded in introducing readers not only to Islamic concepts of sexual relationships and sex education, but also to the ideological battle that is being played out with children's education. At the very heart of this debate we find unanswered and unanswerable questions 
about liberal democracy and how liberal it can be in allowing minorities to flourish in its midst.

The argument basically revolves around the liberal push for increasing individual rights and to see how far such rights can go in relation to responsibilities. As Carole Ulanowsky notes in her contribution titled "Sex Education: Beyond Information to Values," the balance has tipped in favor of rights - a position that is (perhaps) suitable for the mature educator but which "can leave young people morally adrift" (p. 22).

In his overview titled "Values and Sex Education in a Multicultural Society," Mark Halstead demonstrates that this issue is complex and laced with difficulties; however, "the promotion of 'responsible sexual behavior' has become a dominant motif in contemporary sex education in Britain as in other western countries" (p. 236). But who is to decide what is "reasonable"? Parents? Educators? Or that thorn in the side of liberal sex educators: religion?

In stating Islamic positions on this subject, Noibi and Abdul Mabud cover ground that has been well-presented elsewhere; however, the fact that their contributions are neither out of place nor dated illustrates how little educators have learnt from earlier publications by Muslims on this subject. An alternative, less charitable view might conclude that the liberal sex education lobby has learnt too much about the Islamic position and has, as a result, strengthened efforts to undermine it.

For example, Michael Reiss proposes that "the way forward may be for society to make it easier for homosexuals to live in lasting and mutually faithful sexual relationships" (p. 146), and David Carr asks, "How could any civilized person see it as other than a moral advance over bygone tyrannies that homosexual men and women are no longer persecuted?" (p. 170). Going further, Carr says that "liberal modernity has at least freed us from a range of irrational prohibitions." This stand taken by both men demonstrates how "liberal values" can in fact be imposed on young people and, in doing so, force them to alter their own beliefs (and possibly practices). Carr's implication is that the prohibition of homosexuality in scriptures is "irrational," thereby making his own statement "rational." But on what grounds can he make such a judgment? As a number of contributions remind us, education is not value-free, and it is a myth to suggest that the liberal view of sex education is either neutral or morally superior to other views. Abdul Mabud puts it succinctly: "Passivity [and] neutrality" in sex education are themselves "values" (p. 110).

This brings us back to the liberal dilemma and to what is, in my opinion, perhaps the most thought-provoking article in this book. In what he calls "a preliminary but necessary discussion," Mike Bottery effectively sets out the liberals' stall. "The liberal," he says, "will want to present a fundamentalist [sic] 
position as an option for consideration ... whilst a fundamentalist will almost certainly want to present his or her beliefs as unarguable truth." He misses a very important point, however. Indeed, when a liberal presents a number of views for consideration and then says "make up your own mind," he is really saying, "Adopt a liberal worldview." Such a worldview is thus being put forward as a form of "unarguable truth." As a result, the liberal is no different in technique to the fundamentalist who says, "This is the best way, adopt it."

Bottery also mentions Cohen's (1981) belief that "values of self-determination and autonomy are pre-eminent [liberal] values" (p. 151) and goes on to say, "Sex is normally [my emphasis] an act performed between two human beings, and individuals therefore need to reflect upon how their actions will affect their partners" (p. 153). Such consideration should, of course, be taken for granted but, according to Ulanowsky, "Nobody mentions self-control and self-denial - those attributes so necessary for the continuation of civilized existence in contexts beyond the sexual." Thus, she says, "Philosophically ... there appears to be a potential for a mismatch between 'mutual care, consideration and respect,' and 'individual choice"' (p. 26).

We must therefore once again ask those who advocate a liberal form of sex education: Exactly who draws the line between acceptable and unacceptable behavior, between "self-determination and autonomy" and "mutual care"? I emphasized "normally" above because the liberal position demands that society cater to the "abnormal" minorities whose sexual behavior are not shared by the majority. Thus, pedophilia, bestiality, group sex, and other practices must all be condoned in a liberal utopia. But once again, who draws the line and where should it be drawn? Terence McLaughlin suggests that "appropriate" values be used that are "broadly acceptable to society as a whole" (p. 195). But what happens when those values shift as preferences shift? Ulanowsky writes, "the post-modern message has been increasingly lived out" so that "what people individually 'feel' to be the case, is the case," leaving a society of individuals rejecting "the possibility of measuring their preferences by criteria external to those preferences" (p. 21). Noibi reminds us that, in Islam, individual interests are secondary to those of society.

Anyone with a religious viewpoint will find answers by reading this book: cross-curricular Islamic education is essential if sex education is to be dealt with as "part of a belief system" and not in isolation "as a subject in the school curriculum." Others will be able to extract from it many useful quotes which they can then drop into discussions to prove or disprove their own opinion. And everyone with even half an interest in how Westem society is going to deal with Muslims living in its midst - Muslims who are, increasingly, born and raised in the West - should read it, because the arguments contained in 
these essays are a microcosm of the dilemmas being faced in wider but related contexts. "How liberal can liberal society be?" is the big question.

The liberal position "must not entail the acceptance of those who will not listen to others, those who refuse to engage in rational discourse, those who may inhabit the same land geographically but not spiritually. If a liberal, pluralist society goes down that path of acceptance, it sacrifices its soul; and in this situation its judgments will not be worth respecting." My own feeling, after reading this book, is that liberalism is in a downward spiral toward self-destruction. Its soul has long since gone. What has stepped into the void is uncertain of its own identity, for the minute liberalism seeks to impose its own worldview on others it ceases, by definition, to be liberal.

The title of the book is misleading, as only Christian and Muslim religious views on the subject are given; it would have been interesting to have contributions from Jews, Buddhists, Hindus, and others. Nevertheless, the editors have brought together material that deals with the subject in a way that leaves the reader in no doubt about the importance of sex education as an indicator of the moral standards of the wider society. For that reason, this is an important and timely book indeed.

Ibrahim Hewitt Director Association of Muslim Schools (UK) 